\title{
Antioxidative and biological activity of extracts from Orostachys japonicus
}

\author{
Sun-Mi Lim ${ }^{1}$ Hye-Jin Park ${ }^{1}$ (D) $\cdot$ Young-Je Cho ${ }^{1}$ (D) \\ 와송(Orostachys japonicus) 추출물의 항산화 및 생리 활성
}

임선미 ${ }^{1} \cdot$ 박혜진 $^{1} \cdot$ 조영제 ${ }^{1}$

Received: 28 April 2017 / Accepted: 30 May 2017 / Published Online: 31 December 2017

(C) The Korean Society for Applied Biological Chemistry 2017

\begin{abstract}
This study was designed to extracts from Orostachys japonicas were investigated to assess anti-oxidation and biological activity. Phenolic content was maximum of $10.56 \pm 0.32 \mathrm{mg} / \mathrm{g}$ when extracted with $50 \%$ ethanol. In anti-oxidative activity, Orostachys japonicus electric donating activity was higher than $80 \%$ in both water and ethanol extract at $200 \mu \mathrm{g} / \mathrm{mL}$. 2,2'-Azinobis-(3-ethylbenzothiazoline-6-sulfonic acid) radical cation decolorization of both water and ethanol extract was higher than $95.0 \%$ but antioxidant protection factor of water extract was higher than ethanol extract. Thiobarbituric acid reactive substance of ethanol extract was higher than water extract. For antihypertensive effect determination, angiotesin converting enzyme of water and ethanol extract showed 6.67 and $7.98 \%$ each at $200 \mu \mathrm{g} / \mathrm{mL}$. Ethanol extract of $200 \mu \mathrm{g} / \mathrm{mL}$ showed xanthin oxidase inhibitory effect of $60.85 \%$ but was not shown with water extract. Orostachys japonicus ethanol extract showed higher tyrosinase inhibitory activity of $64.59 \%$ which was higher than kojic acid of control indicating higher whitening effect. In anti-wrinkle effect, ethanol extract at $50-200 \mu \mathrm{g} / \mathrm{mL}$ showed collagenase inhibitory effect of $75.95-85.02 \%$ which was higher than $68.91-76.64 \%$ of epigallocatechin-gallate of control group. $50 \%$ ethanol extract showed higher elastase inhibitory activity than water extract. Therefore,
\end{abstract}

Young-Je Cho $(\bowtie)$

E-mail: yjcho@knu.ac.kr

${ }^{1}$ School of Food science \& Biotechnology/Food \& Bio-Industry Research Institute, Kyungpook National University, 80 University Street, Bukgu, Daegu 41566, Republic of Korea

This is an Open Access article distributed under the terms of the Creative Commons Attribution Non-Commercial License (http://creativecommons. org/licenses/by-nc/3.0/) which permits unrestricted non-commercial use, distribution, and reproduction in any medium, provided the original work is properly cited.
Orostachys japonicus extracts were identified to have high antiwrinkle effect. These results identify anti-oxidative activity, gout prevention, whitening effect, and anti-wrinkle effect which indicate the possibility as a source for functional material.

Keywords Anti-oxidative activities · Beauty food · Biological activities $\cdot$ Healthy food $\cdot$ Orostachys japonicus

\section{서 론}

와송(Orostachys japonicus A. Berger)은 오래된 기와지붕 위나 깊은 산의 바위 위에 자라는 돌나무과(Crassulaceae)의 여러해 살이 식물로 버들잎 모양으로 줄기를 둘러싸고 무더기로 자라 는데, 자라는 모양이 소나무 잎이나 꽃을 닮아서 와송 또는 바 위솔이라 불린다. 여름부터 가을에 걸쳐 채취하며 뿌리를 제거 한 전초를 말려서 약용으로 사용하는데, 우리나라에서 오래 전 부터 민간요법으로 간염, 종기에 대한 면역작용, 지혈제 및 암 치료제 등으로 사용되어 왔으며(Kim 1984), 와송에 존재하는 것으로 알려진 phytochemical compound로 sterol, triterpenoid 류, flavonoid류 및 페놀성 화합물 등의(Park 등, 1991; 1994) 분리된 유용한 물질들이 소화기계통의 암에 효능이 있는 것으 로 보고되면서 최근 이에 대한 연구가 더욱 활발히 진행되고 있다(Park 등, 2000; Kim 등, 2012; Won 등, 2014). 또한 약 리적으로 혈관수축작용과 호흡흥분작용, 내장기관의 긴장증강작 용(Kim 1984), 항산화 및 항암효과(Kwon과 Han 2004) 등 다 양한 생리활성에 대한 연구도 상당수 보고되고 있다. 와송의 주 요 성분으로는 triterpenoid류인 friedelin, epi-friedianol, glutinone, glutinol과 sterol 계열물질인 $\beta$-sitosterol, campesterol 등이 있으 며 aromatic acid인 4-hydroxy benzoic acid, 3,4-dihydroxybenzoic acid과 tannin 계열 물질인 gallic acid와 flavonoid인 kaempferol, 
quercetin 등이 보고되고 있다(Choi 등, 2008).

소득수준의 향상과 더불어 풍요로운 삶을 영위하고 있으나, 이로 인한 식생활의 변화에 기인하여 성인병 질환이 증대되고, 고령화 사회에 따라 높아진 삶의 질에 대한 인식이 요구되고 있는 실정이다(Jung과 Kim 2003; Kim 등, 2004b). 인체 내에 서 에너지 생산을 위한 산화과정 중에 많은 양의 유해한 활성 산소들이 생성되며, 이들 활성산소는 생체 내 제거 기작에 의 해 대부분 소멸이 되지만 항산화 방어계의 균형을 무너뜨려 각 종 질환의 원인이 되기도 한다(Aruoma 1998). 현재까지 개발된 항산화제는 tocopherol류, carotenoid, ascorbic acid, phenol류, 아미노산류, flavonoids, tannin류, phenol성 화합물 및 셀레늄 등의 천연 항산화제와 tert-butylated hydroxytoluene (BHT), tert-butylated hydroxyanisol (BHA), tert-butyl hydroquinone 등의 합성 항산화제가 있으나, 이러한 합성 항산화제의 경우 독 성이나 부작용 등 이용상의 문제로 식품에 이용이 제한되고 있 다(Choe와 Yang 1982). 또한 생체효소 및 지방 변이성 독성으 로 인해 인체에 암을 유발할 수도 있다고 알려진 합성 항산화 제에 비해 천연 항산화제들은 인체에 해를 끼치지 않는 것으로 알려져 있으나 비교적 항산화력이 낮아, 안전하고 효력이 강한 천연 항산화제의 연구 개발이 필요한 실정이다(Kyrtopoulos 1989). 이에 따라 최근 들어 식물소재의 자원에 함유되어 있는 생리활성 소재들을 천연항산화제 원료로 이용하려는 시도가 다 양하게 이루어지고 있다(Huang 등, 1992).

식물에 존재하는 폴리페놀 화합물은 효소 단백질 같은 거대 분자들과 결합하는 성질을 가지고 있으며, 이로 인해 항균 및 항산화 효능을 비롯하여 다양한 생리활성 등을 나타내는 것으 로 알려져 있다(Azuma 등, 1999; Park 등, 2003). 천연 항산화 제, 기능성 화장품, 건강기능식품 및 신약 개발을 위한 기능성 phytochemicals 물질에 관한 연구는 약리성 식물류와 이들 식물 체 내에 천연적으로 함유되어 있는 물질을 활용하여 다양한 측 면에서의 생리활성 규명을 중심으로 진행되고 있다(Larson 1988; Nam과 Kang 2000;Kim 등, 2004a; Ju 등, 2006). 따라서 본 연구에서는 한국산 약용식물인 와송으로부터 페놀성 물질을 분 리하여 생체 내 생리활성 효과에 대한 기초자료를 얻고자 in $v i t r o$ 에 의한 항산화 활성과 고혈압 예방 효과, 통풍 억제 효과 확인을 통해 약리성 식품 생리활성을 검증하였으며 미백효과, 주름개선효과 등의 기능성 미용식품 활성을 탐색하였다.

\section{재료 및 방법}

\section{실험재료}

본 연구에 사용한 와송(Orostachys japonicus)은 2015년 경북 김천소재의 와송 재배농장에서 구입하여 전초를 천일건조 시킨 후, $40 \mathrm{mesh}$ 로 분쇄하여 $4^{\circ} \mathrm{C}$ 에서 저온저장하며 사용하였다.

\section{추출물의 제조}

시료 추출은 열수 추출물의 경우 와송 분말 $1 \mathrm{~g}$ 에 증류수 200 $\mathrm{mL}$ 를 가하고 용매가 $100 \mathrm{~mL}$ 가 될 때까지 가열하여 냉각시킨 후 24시간 동안 상온에서 교반하여 추출하였으며, methanol, acetone, butanol 및 ethanol 추출물은 와송 분말 $1 \mathrm{~g}$ 에 100 $\mathrm{mL}$ 의 각 용매를 가한 후 침지시켜 24 시간 동안 상온에서 교반
하여 추출하였다. 추출물은 Whatman No. 1 filter paper (Whatman, Maidstone, UK)로 여과하여 필요에 따라 rotary vacuum evaporator (Eyela NE, Tokyo, Japan)에서 농축하여 시료의 총 phenolics 농도 구간을 조절하여 사용하였다.

\section{총 phenol성 화합물 정량}

총 phenolics 함량은 Folin과 Denis(1912)의 방법에 준하여 측 정하였으며, 시료 추출물 $1 \mathrm{~mL}$ 에 $95 \%$ ethanol $1 \mathrm{~mL}$ 와 증류수 $5 \mathrm{~mL}$ 를 첨가하고 $1 \mathrm{~N}$ Folin-Ciocalteu reagent (Junsei, Tokyo, Japan) $0.5 \mathrm{~mL}$ 를 넣어 잘 섞은 후 5 분 뒤 $5 \% \quad \mathrm{Na}_{2} \mathrm{CO}_{3} 1 \mathrm{~mL}$ 를 첨가하고 1 시간 동안 암실에서 반응시킨 후 UV-visible spectrophotometer (Optizen 3220UV Mecasys, Daejeon, Korea) 로 $725 \mathrm{~nm}$ 에서 흡광도를 측정하여 gallic acid를 이용한 표준곡 선으로부터 양을 환산하였다.

\section{항산화 효과 측정}

1,1-diphenyl-2-picrylhydrazyl (DPPH) radical에 대한 소거활성 은 Blois(1958)의 방법에 준하여 측정하였으며, 저해율 $(\%)$ 은 (1반응구의 흡광도/대조구의 흡광도 $\times 100$ 으로 나타내었다. 2,2'Azinobis-(3-ethylbenzothiazoline-6-sulfonic acid) radical cation decolorization (ABTS) 측정은 Pellegrin 등(1998)의 방법에 준 하여 저해율 $(\%)$ 는 (1-반응구의 흡광도/대조구의 흡광도 $) \times 100$ 으 로 나타내었다. Antioxidant protection factor (PF) 측정은 Andarwulan과 Shetty (1999)의 방법으로 반응구의 흡광도/대조 구의 비로 나타내었다. Thiobarbituric acid reactive substance (TBARs) 저해측정은 Buege와 Aust(1978)의 방법에 준하여 측 정하였으며, 저해율 $(\%)$ 은 (1-반응구의 흡광도/대조구의 흡광도) $\times 100$ 으로 나타내었다.

\section{Angiotensin converting enzyme (ACE) 저해효과 측정}

$\mathrm{ACE}$ 저해효과 측정은 Cushman과 Cheung(1971)의 방법에 준 하여 측정하였다. 반응구는 $0.3 \mathrm{M} \mathrm{NaCl}$ 을 함유한 $0.1 \mathrm{M}$ potassium phosphate buffer $(\mathrm{pH} 8.3$ )에 녹인 기질액 $2.5 \mathrm{mM}$ hippuryl-L-histidyl-L-leucine (HHL, Sigma-Aldrich Co., Louis, $\mathrm{MO}$, USA) $0.15 \mathrm{~mL}$ 와 $0.25 \mathrm{unit} / \mathrm{mL} \mathrm{ACE}$ (Sigma-Aldrich Co., Louis, MO, USA) $0.1 \mathrm{~mL}$ 와 시료 $0.1 \mathrm{~mL}$ 을 넣어 혼합하였으며, 대조구에는 시료 대신 증류수를 $0.1 \mathrm{~mL}$ 를 첨가하여 $37^{\circ} \mathrm{C}$ 에서 30 분간 반응시키고, 종료시약 $1 \mathrm{~N} \mathrm{HCl} 0.25 \mathrm{~mL}$ 를 첨가한 후 ethyl acetate $3 \mathrm{~mL}$ 을 추가하였다. 이후 Ethylacetate층만 분취하 여 용매를 증류 건조시켜 hippuric acid를 추출하고, 추출된 hippuric acid를 $2 \mathrm{~mL}$ 의 증류수를 사용하여 재용해시켜 $280 \mathrm{~nm}$ 에서 흡광도를 측정하였다. $\mathrm{ACE}$ 저해율 $(\%)$ 은 (1-시료의 Hippuric acid 함량/대조구의 Hippuric acid 함량 $) \times 100$ 으로 계산 하였다.

\section{Xanthine oxidase (XOase) 저해효과 측정}

Xanthine oxidase 저해효과 측정은 Stirpe와 Corte(1969)의 방법 에 준하여 측정하였다. 반응구는 $0.1 \mathrm{M}$ potassium phosphate buffer (pH 7.5)에 녹인 기질액 $2 \mathrm{mM}$ xanthine $3 \mathrm{~mL}$ 에 0.05 $\mathrm{U} / 0.1 \mathrm{~mL}$ xanthine oxidase $0.1 \mathrm{~mL}$ 과 시료 $0.3 \mathrm{~mL}$ 를 넣고 대 조구에는 시료 대신 증류수를 $0.3 \mathrm{~mL}$ 첨가하여 $37^{\circ} \mathrm{C}$ 에서 5 분 간 반응시키고 종료시약 $20 \% \mathrm{TCA} 1 \mathrm{~mL}$ 를 가한 후 반응액을 
원심분리하여 단백질을 제거하고 생성된 uric acid를 $292 \mathrm{~nm}$ 에 서 흡광도를 측정하여, 저해율 $(\%)$ 은 (1-시료의 uric acid 함량/ 대조구의 uric acid 함량 $) \times 100$ 으로 계산하였다.

\section{Tyrosinase 저해효과 측정}

Tyrosinase 저해효과 측정은 Hearing(1987)의 방법에 준하여 측 정하였다. 반응구는 $0.1 \mathrm{M}$ sodium phosphate buffer $(\mathrm{pH}$ 6.8) $2.3 \mathrm{~mL}$ 와 기질액 $1.5 \mathrm{mM}$ L-tyrosine 용액 $0.4 \mathrm{~mL}$ 의 혼합액에 $250 \mathrm{U} / \mathrm{mL}$ mushroom tyrosinase (Sigma-Aldrich Co., Louis, $\mathrm{MO}, \mathrm{USA}) 0.1 \mathrm{~mL}$ 와 시료 $0.2 \mathrm{~mL}$ 를 넣고 대조구에는 시료 대 신 증류수를 $0.2 \mathrm{~mL}$ 를 첨가하여 $37^{\circ} \mathrm{C}$ 에서 20 분간 반응시켜 생 성된 L-3,4-dihydroxyphenylalanine (DOPA) chrome을 흡광도 $475 \mathrm{~nm}$ 에서 측정하여 저해율 $(\%)$ 은 (1-시료의 absorbance/대조 구의 absorbance) $\times 100$ 으로 계산하였다.

\section{Collagenase, elastase 저해효과 측정}

주름개선 효과를 확인하기 위해 collagenase 저해활성과 elastase 저해활성을 측정하였다. Collagenase 저해활성 측정은 Wûnsch 과 Heindrich(1963)의 방법에 준하여 반응구는 $0.1 \mathrm{M}$ tris- $\mathrm{HCl}$ buffer ( $\mathrm{pH} 7.5$ )에 $4 \mathrm{mM} \mathrm{CaCl} 2$ 를 첨가하여, $0.3 \mathrm{mg} / \mathrm{mL}$ 4phenylazobenzyloxycarbonyl-Pro-Leu-Gly-Pro-D-Arg를 녹인 기 질액 $0.25 \mathrm{~mL}$ 와 시료용액 $0.1 \mathrm{~mL}$ 의 혼합액에 $0.2 \mathrm{mg} / \mathrm{mL}$ collagenase $0.15 \mathrm{~mL}$ 를 첨가하여 실온에서 20 분간 방치한 후 $6 \%$ citric acid $0.5 \mathrm{~mL}$ 을 넣어 반응을 종료시키고 ethyl acetate $1.5 \mathrm{~mL}$ 을 첨가하여 $320 \mathrm{~nm}$ 에서 흡광도를 측정하여 저해율 $(\%)$ 은 (1-시료의 absorbance/대조구의 absorbance) $\times 100$ 으로 계산하 였다. Elastase 저해효과 측정은 Kraunsoe 등(1996)의 방법에 준하여 반응구는 $0.2 \mathrm{M}$ Tris- $\mathrm{HCl}$ buffer $(\mathrm{pH} 8.0) 1 \mathrm{~mL}$ 와 기 질액 $0.8 \mathrm{mM} \mathrm{N}$-succinyl-(Ala) $)_{3}$ - $\rho$-nitroanilide 용액 $0.1 \mathrm{~mL}$ 의 혼합액에 $1.0 \mathrm{U} / \mathrm{mL}$ porcine pancreatice elastase (PPE) (SigmaAldrich Co., Louis, MO, USA) 효소용액 $0.1 \mathrm{~mL}$ 와 시료 0.1 $\mathrm{mL}$ 를 넣고 대조구에는 시료 대신 증류수 $0.1 \mathrm{~mL}$ 를 첨가하여 $25^{\circ} \mathrm{C}$ 에서 20 분간 반응시켜 $\rho$-nitroaniline 생성량을 $410 \mathrm{~nm}$ 에서 흡광도를 측정한 후 저해율 $(\%)$ 은 (1-시료의 absorbance/대조구 의 absorbance) $\times 100$ 으로 계산하였다.

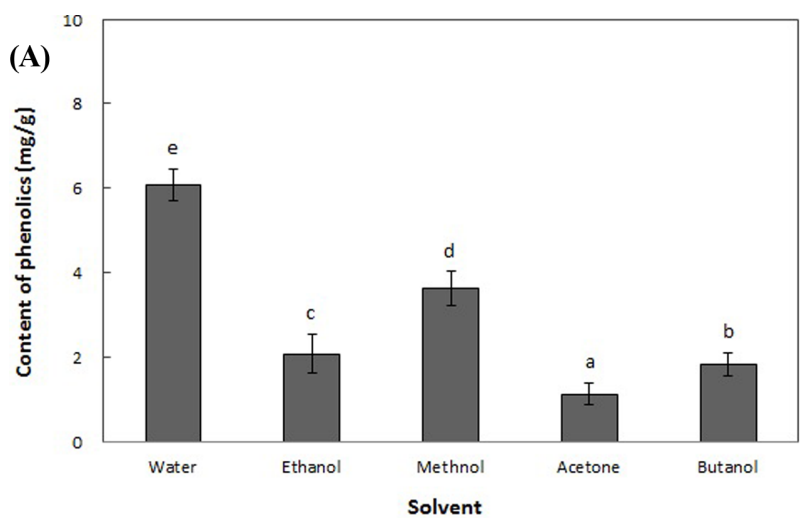

\section{통계처리}

본 실험의 결과는 3-6회 반복하여 측정한 결과값을 평균 \pm 표준 편차 $($ mean $\pm \mathrm{SD}$ 로 표기하였으며, SPSS 23 for windows (Statistical Package for Social Science, Chicago, IL, USA)를 이용하여 분산분석 및 Duncan's multiple range test one-way $\mathrm{ANOVA}$ 으로 $5 \%$ 이내에서 유의성을 검정하였다.

\section{결과 및 고찰}

용매 종류, 용매 농도가 총 phenol성 물질 용출에 미치는 영향 식물계에 널리 분포되어 있는 phenol성 물질은 식물의 2 차 대 사산물 중 하나로 다양한 구조와 분자량을 가지며, phenolic hydroxyl기를 가지고 있어 단백질 등의 거대 분자들과 결합하 는 성질을 가지고 있다. 이러한 특성이 phenol성 물질의 항산 화 효능 및 항균 활성 등과 같은 다양한 생리활성을 나타내는 것으로 보고되고 있다(Hearing 1987; Choi 등, 2003). 와송으로 부터 총 phenol성 물질을 추출하기 위해 water, ethanol, methanol, acetone, butanol과 같이 다양한 용매를 사용하여 phenol성 물질 의 용출량을 비교하였다. 그 결과 Fig. $1 \mathrm{~A}$ 와 같이 methanol> ethanol $>$ butanol $>$ aceton순으로 용출량이 각각 $3.63 \pm 0.40,2.07$ $\pm 0.46,1.83 \pm 0.25,1.12 \pm 0.25 \mathrm{mg} / \mathrm{g}$ 으로 나타났다. 이는 유근피를 이용하여 다양한 용매로 추출하였을 때, methanol에서 추출수율 이 가장 높게 나타났다는 $\operatorname{Shin}(2003)$ 의 보고와 유사한 결과로 와송의 phenol성 물질이 극성용매에서 용해도가 높은 것으로 확 인되었다. 하지만 methanolo은 식용으로 사용할 수 없는 용매로 식품산업 적용에 어려움이 있을 것으로 판단하여, 비교적 추출 수율이 높고 식품 원료로 적용이 가능한 물과 ethanol을 추출 용매로 이용하여 ethanol 농도별 총 phenol성 물질의 용출량을 확인하였다. 그 결과는 Fig. $1 \mathrm{~B}$ 와 같이 $50 \%$ ethanol 추출물에 서 $10.56 \pm 0.32 \mathrm{mg} / \mathrm{g}$, 열수 추출물에서는 $6.08 \pm 0.38 \mathrm{mg} / \mathrm{g}$ 을 나타 내어 $50 \%$ ethanol 추출물에서 총 phenol성 물질 함량이 가장 높은 것을 확인할 수 있었다. 이는 ethanol 농도에 따라 용출되 어 나오는 총 phenol성 물질의 종류가 다르기 때문인 것으로 판단되었으며, ethanol 농도에 따른 함량의 차이는 크지 않았다.

Fig. 1 Effect of (A) different solvent and (B) ethanol concentration on total phenolics of extracts from Orostachys japonicus. Mean \pm standard deviation $(n=3)$. Means with different letters $(\mathrm{a}-\mathrm{j})$ above the bars are significantly different at $p<0.05$ by a Duncan's multiple range tests 

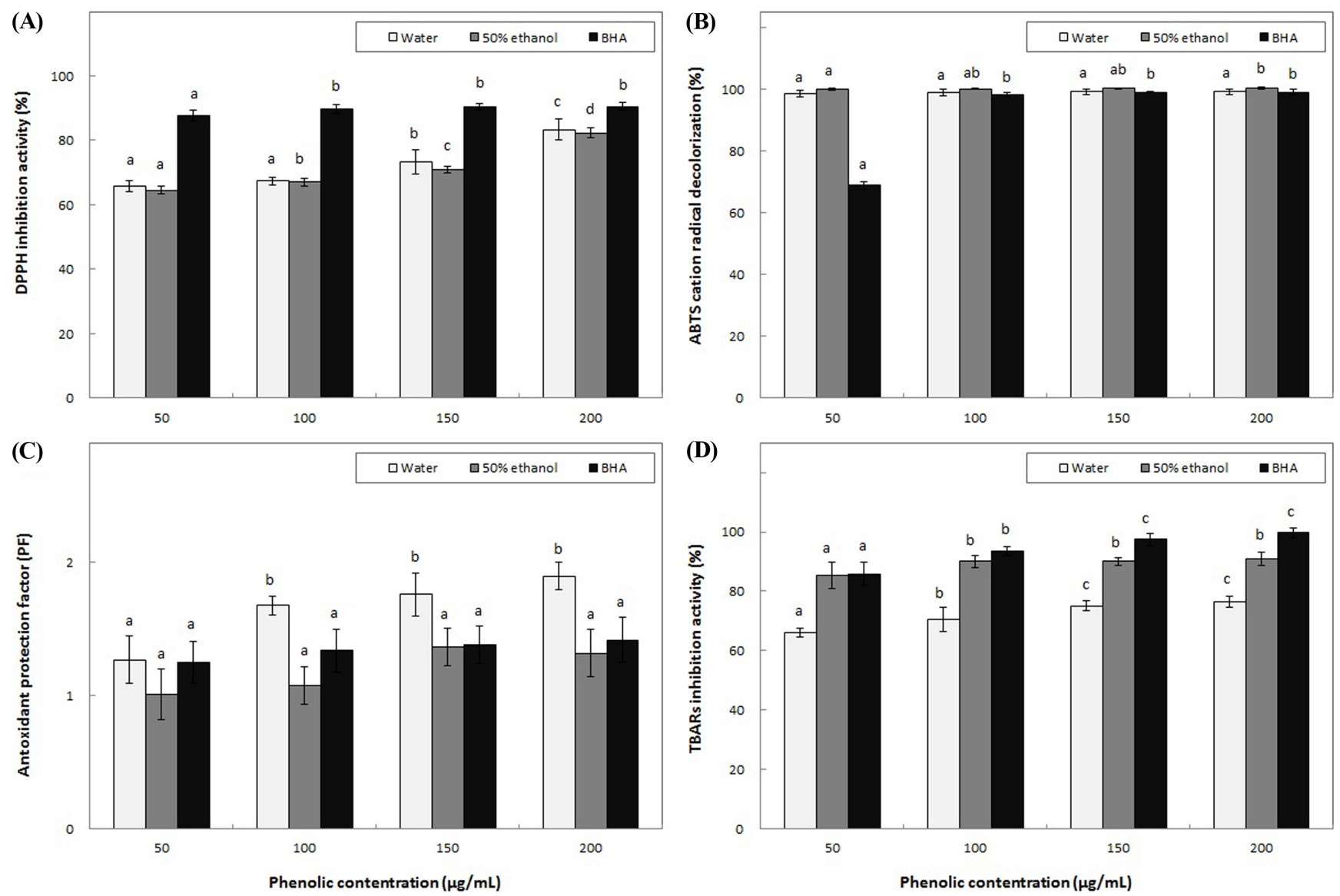

Fig. 2 Antioxidant activity of water and 50\% ethanol extract from Orostachys japonicus. (A): DPPH radical inhibitory activity, (B): ABTS radical scavenging activity, $(\mathrm{C})$ : antioxidant protection factor $(\mathrm{PF}),(\mathrm{D})$ : TBARs inhibitory activities. Mean \pm standard deviation $(n=6)$. Means with different letters (a-d) above the bars are significantly different at $p<0.05$ by a Duncan's multiple range test

Lee 등(2009)은 와송의 잎, 줄기, 뿌리 부위별로 나누어 물과 ethanol 추출물의 총 phenol성 물질의 함량을 측정하였으며, 그 결과는 ethanol 추출물에서 잎(14.62 $\mathrm{mg} / \mathrm{g}$ of dry sample), 줄 기 $(4.29 \mathrm{mg} / \mathrm{g}$ of dry sample), 뿌리 $(1.70 \mathrm{mg} / \mathrm{g}$ of dry sample $)$ 로 나타났으며, 물 추출물에서는 잎 $(1.07 \mathrm{mg} / \mathrm{g}$ of dry sample), 줄기 $(0.98 \mathrm{mg} / \mathrm{g}$ of dry sample), 뿌리 $(0.68 \mathrm{mg} / \mathrm{g}$ of dry sample $)$ 로 나타나 와송 전초를 이용한 본 연구결과와 유사한 양상을 나타내는 것을 확인할 수 있었다. 이상의 결과에 따라 가장 높 은 총 phenol성 물질 함량을 나타낸 $50 \%$ ethanol 추출물과 열 수 추출물을 이용하여 $50-200 \mu \mathrm{g} / \mathrm{mL}$ phenolics 농도로 조절한 후 이후 실험을 진행하였다.

\section{와송 추출물의 항산화 효능}

항산화 효능을 검증하기 위해 DPPH radical 저해효과, ABTS radical 저해효과, PF, TBARs 저해 효과를 확인하였다.

전자공여능 측정에 사용된 $\mathrm{DPPH}$ 는 스스로가 지니고 있는 흡 수 스펙트럼을 나타내지만, phenol성 물질과 같이 수소에 전자 를 제공하는 전자공여체와 반응하게 되면 전자 hydrogen radical 을 받아 phenoxy radical을 생성하여 흡수 스펙트럼 band가 사 라지게 되고 안정한 상태의 분자가 되며 진한 보라색이 점점 옅 어지며 흡광도가 감소하게 된다(Aoshima 등, 2004). 와송의
$\mathrm{DPPH}$ radical 저해효과를 측정한 결과는 Fig. $2 \mathrm{~A}$ 와 같이 50 $200 \mu \mathrm{g} / \mathrm{mL}$ phenolics 전 농도구간에서 열수 추출물의 경우 $65.85-83.21 \%, 50 \%$ ethanol 추출물의 경우 $64.45-82.31 \%$ 의 효 능을 나타내어 두 추출물 간의 전자공여능의 격차가 크지 않음 을 알 수 있었으며, phenol성 물질의 농도가 증가할수록 전자공 여능 또한 증가하는 농도 의존적인 경향을 확인할 수 있었다. Koh 등(2005)은 석류씨 추출물의 항산화 효능을 측정한 결과, 열수 추출물, ethanol 추출물 및 석류씨 oil이 $1,000 \mathrm{ppm}$ 의 농도 에서 각각 $18.8,28.5,9.7 \%$ 의 전자공여능을 나타낸다고 보고하 여, 와송 추출물의 항산화 활성이 매우 우수함을 알 수 있었다.

추출물들의 상대적인 항산화 측정은 ABTS free radical이 추 출물에 함유된 항산화 물질에 의해 제거되면서 radical이 지니 는 특유의 색인 청록색이 탈색되는 정도를 측정하여 확인할 수 있다(Pellegrin 등, 1998). 와송 추출물의 ABTS 저해력 측정 결 과는 Fig. $2 \mathrm{~B}$ 와 같이 열수와 $50 \%$ ethanol 추출물 모두 $50 \mu \mathrm{g} /$ $\mathrm{mL}$ phenolic 저농도에서도 $95.0 \%$ 이상의 높은 $\mathrm{ABTS}$ radical 저해활성을 나타내어 친수성 및 lipophilic 물질에 대한 항산화 력이 매우 우수한 것을 확인할 수 있었다. 대조구인 $\mathrm{BHA}$ 가 $50-200 \mu \mathrm{g} / \mathrm{mL}$ phenolic 농도에서 68.81-98.96\%를 나타낸 것과 비교하였을 때, 와송 추출물이 상당히 높은 항산화력을 가지고 있음을 확인할 수 있었다. 


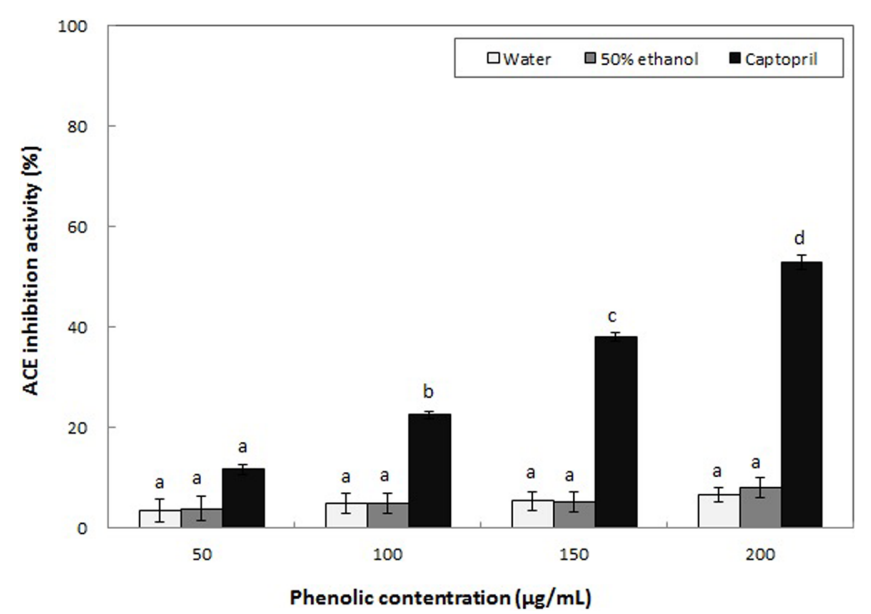

Fig. 3 Angiotensin converting enzyme (ACE) inhibitory activity of water and $50 \%$ ethanol extract from Orostachys japonicus. Means with different letters (a-d) above the bars are significantly different at $p<0.05$ by a Duncan's multiple range test

와송 열수 추출물과 $50 \%$ ethanol 추출물의 $\mathrm{PF}$ 를 측정한 결 과는 Fig. $2 \mathrm{C}$ 와 같이 열수 추출물이 $50 \%$ ethanol 추출물보다 상대적으로 높은 $\mathrm{PF}$ 값을 나타내었으며, 대조구인 $\mathrm{BHA}$ 가 50$200 \mu \mathrm{g} / \mathrm{mL}$ 농도에서 1.25-1.42 PF를 나타낸 것과 비교하여 열 수 추출물 $50-200 \mu \mathrm{g} / \mathrm{mL}$ phenolic 농도 구간에서 BHA 보다 높은 1.27-1.90 PF의 매우 높은 항산화력을 나타내었다. 또한 phenol성 물질의 농도가 증가함에 따라 $\mathrm{PF}$ 의 효과가 유의적으 로 높아지는 것을 보아 추출물의 phenol성 물질 함량에 대해 농도 의존적으로 항산화 효과가 나타나는 것을 확인할 수 있었 다. 오디 추출물의 지용성 물질에 대한 항산화력은 ethanol 추 출물에서 $1.25 \mathrm{PF}$ 라는 $\mathrm{Kim}(2006)$ 의 연구 결과와 완두콩에 함 유된 phenol성 물질은 $1.3 \mathrm{PF}$ 라는 Kim 등(1995)의 연구 결과 보다 비교하였을 때, 본 연구에 사용된 와송 추출물의 항산화 력이 더 우수한 것을 알 수 있었다. $\mathrm{PF}$ 의 경우 일반적으로 1.2 $\mathrm{PF}$ 를 기준으로 그 이상의 경우 지용성 물질에 대한 항산화력이 높은 것으로 판단하는데, 본 연구에 사용된 와송 추출물의 경 우 지용성 물질에 대한 항산화력이 매우 뛰어난 것을 확인할 수 있었다.

산화과정에서 생성되는 지질과산화물인 malondialdehyde의 함 량을 확인하여 지용성 물질에 대한 항산화 효과를 확인할 수 있는데, 와송 추출물의 TBARs 저해효과를 측정한 결과는 Fig. $2 \mathrm{D}$ 와 같이 열수 추출물보다 $50 \%$ ethanol 추출물에서 TBARs 저해효과가 더 높게 나타났으며, $50 \%$ ethanol 추출물의 경우 $50-200 \mu \mathrm{g} / \mathrm{mL}$ phenolics의 전 농도 구간에서 $82.81-91.88 \%$ 의 항산화력을 나타내었다. 이는 대조구인 BHA와 거의 대등한 수 준의 항산화력이었으며, 총 phenol성 물질의 농도가 높아질수록 항산화력이 증가하는 것이 관찰되었으나 그 차이는 다소 크지 않았다. 따라서 와송 추출물의 전자공여능, $\mathrm{ABTS}$ 억제효능, $\mathrm{PF}$, TBARs 저해효능의 우수성을 확인하였고, 이를 통해 와송 추출 물이 수용성 및 지용성 물질 모두에 대하여 매우 우수한 항산 화 자원인 것으로 판단할 수 있었다.

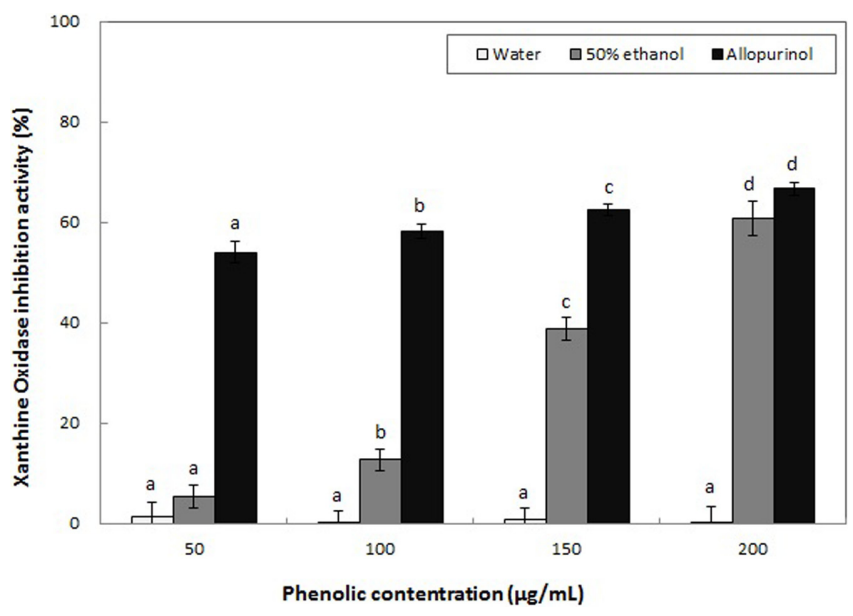

Fig. 4 Xanthine oxidase inhibitory activity of water and 50\% ethanol extract from Orostachys japonicus. Means with different letters (a-d) above the bars are significantly different at $p<0.05$ by a Duncan's multiple range test

와송 추출물의 angiotensin converting enzyme (ACE) 억제효과 고혈압은 우리나라에서 암 다음으로 많이 발생되는 대표적인 질 환 중 하나이며, 혈압을 조절하는 renin-angiotensin system에서 $\mathrm{ACE}$ 는 혈압 상승 조절에 관여하는 중요한 효소로 알려져 있다 (Miyoshi와 Richard 1975). 본 연구에서 와송 추출물의 $\mathrm{ACE}$ 저해활성을 측정한 결과는 Fig. 3과 같이 $200 \mu \mathrm{g} / \mathrm{mL}$ phenolic 농도에서 열수 추출물은 $6.67 \%$ 의 저해율을 나타내었고, $50 \%$ ethanol 추출물은 $7.98 \%$ 의 저해율을 나타내었다. 반면 $\mathrm{ACE}$ 저 해제로 잘 알려진 항고혈압약 captopril을 대조구로 저해율을 확 인한 결과 $200 \mu \mathrm{g} / \mathrm{mL}$ 에서 $52.81 \%$ 의 저해율을 나타내어, 와송 추출물의 $\mathrm{ACE}$ 저해활성은 매우 낮은 것을 확인할 수 있었다.

\section{와송 추출물의 xanthine oxidase (XOase) 억제효과}

XOase는 purine 대사에서 xanthine 또는 hypoxanthine으로부터 urate 생성에 관여하는 주요 효소이며, 체내에서 urate 생성이 증 가하게 되면 혈장 내 뼈에 축적되면 심한 통증을 유발하는 통 풍(gout)을 발생시키며, 신장에 침착되면 신장 질환을 야기시키 는 것으로 알려져 있다(Noro와 Fukushima 1988). XOase는 분 자상의 산소를 수소 수용체로 이용해 xanthine을 uric acid형으 로 산화하는 반응을 촉매하는 작용을 하는데, XOase를 저해하 면 free radical 생성을 저해하기 때문에 생물학적으로 중요한 의의를 가진다. 와송 추출물의 XOase 저해활성을 측정한 결과 는 Fig. 4와 같이 열수 추출물에서는 억제효과가 거의 관찰 되 지 않았으나, $50 \%$ ethanol 추출물 $200 \mu \mathrm{g} / \mathrm{mL}$ phenolic 농도에 서 $60.85 \%$ 의 억제효과를 관찰할 수 있었다. 열수 추출물과 달 리 $50 \%$ ethanol 추출물이 상대적 XOase 저해활성이 높게 나타 난 것은 $50 \%$ ethanol 추출물에 용출된 생리활성을 가지는 총 phenol성 물질의 종류별 차이에 의한 것으로 추측되었다. 현재 시중에 통풍 치료약으로 사용되고 있는 allopurinol을 대조구로 사용하여 XOase 저해효과를 확인한 결과, allopurinol $200 \mu \mathrm{g} /$ $\mathrm{mL}$ 농도에서 $66.68 \%$ 의 억제효과를 나타내어 와송 $50 \%$ 


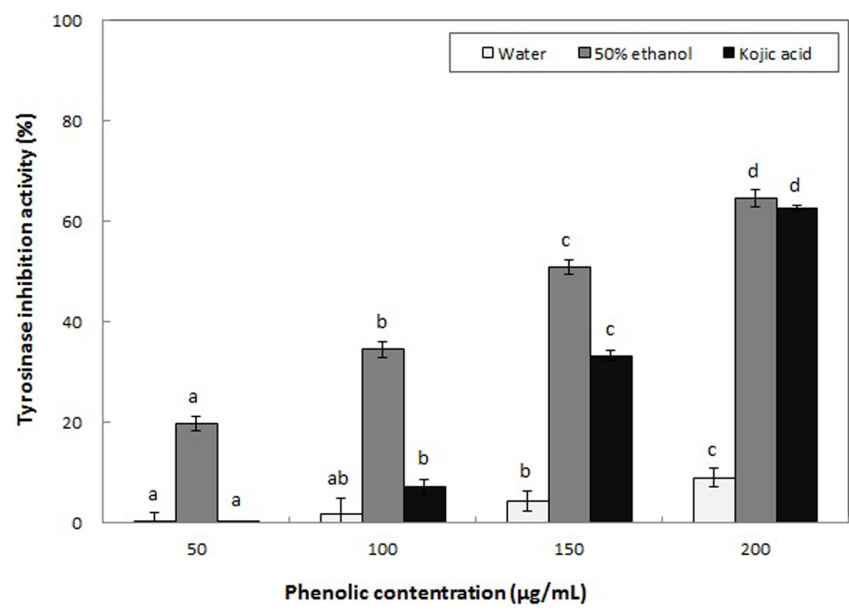

Fig. 5 Tyrosinase inhibitory activity of water and 50\% ethanol extract from Orostachys japonicus. Means with different letters (a-d) above the bars are significantly different at $p<0.05$ by a Duncan's multiple range test

ethanol 추출물 $200 \mu \mathrm{g} / \mathrm{mL}$ phenolics 농도와 비슷한 수준의 저 해효과를 확인할 수 있었다. 이상의 결과를 통해 와송 $50 \%$ ethanol 추출물의 XOase 저해활성이 높은 것을 확인할 수 있었 으며, 추가 연구를 통해 와송 추출물이 통풍 치료제로써도 활 용이 가능할 것으로 기대되었다.

\section{와송 추출물의 tyrosinase 억제효과}

Tyrosinase는 구리를 함유한 효소로서 melanin 합성의 초기단계 인 L-tyrosine에서 L-DOPA로 전환시키는 hydroxylase로서의 활 성과 L-DOPA에서 L-dopaquinone으로 전환시키는 dopaoxidase 로서의 활성을 모두 가지고 있어 두 가지 단계의 반응을 촉진 시키는 melanin 합성의 key enzyme으로 작용하며, 최종적으로 melanin을 형성하는데 이렇게 생성된 melanin은 피부 흑화와 피 부 질환의 원인이 된다(Imokawa와 Mishima 1980). 따라서 melanin 생합성 과정에서 중요한 역할을 하는 tyrosinase를 억제 하게 되면 피부의 melanin 색소 생성을 조절하여 미백효능을 나타내는 물질로 사용할 수 있어 tyrosinase 억제제에 대한 연 구가 활발히 진행되고 있다(Laskin과 Piccinini 1986). 와송 추 출물의 tyrosinase 억제효과를 측정한 결과는 Fig. 5 와 같이 와 송 열수 추출물에서는 tyrosinase 억제효과가 매우 낮게 측정되 었으나, $50 \%$ ethanol 추출물 $200 \mu \mathrm{g} / \mathrm{mL}$ phenolic 농도에서는 $64.59 \%$ 로 나타나 상대적으로 높은 tyrosinase 억제효과를 확인 할 수 있었다. 한약재 복합 추출물을 $1,000 \mu \mathrm{g} / \mathrm{mL}$ 의 농도로 처 리했을 때 $34.0 \%, 5,000 \mu \mathrm{g} / \mathrm{mL}$ 의 농도로 처리하였을 때 $65.0 \%$ 이상의 tyrosinase 저해활성이 나타난다고 보고한 Kim 등(2011) 의 결과와 비교하였을 때, 와송 $50 \%$ ethanol 추출물의 억제효 능이 더 우수함을 확인할 수 있었다. 와송 추출물의 tyrosinase 억제효과는 phenol성 물질 함량의 농도 의존적으로 증가하였으 며, 이는 유의적으로 나타나는 것을 관찰할 수 있었으며, 본 연 구 결과를 통해 mushroom tyrosinase에 직접적인 저해활성이 다소 있는 것으로 판단되었다. 또한 대조구인 kojic acid보다 와 송 $50 \%$ ethanol 추출물의 저해효능이 더 우수한 것으로 나타 나, 와송 $50 \%$ ethanol 추출물이 향후 melanin 성성을 억제시키
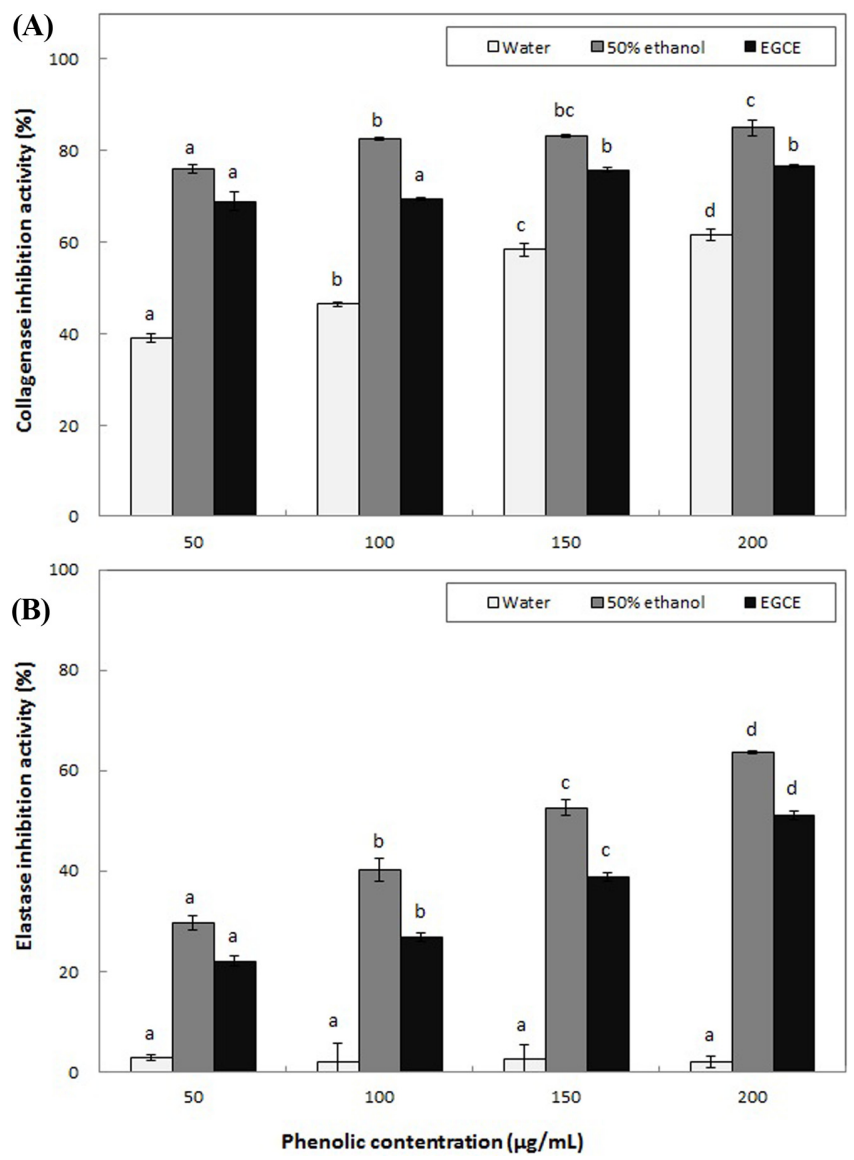

Fig. 6 Anti-wrinkle inhibitory activity of water and $50 \%$ ethanol extract from Orostachys japonicus. (A) collaganase inhibitory activity and (B) elastase inhibitory activity. Means with different letters (a-d) above the bars are significantly different at $p<0.05$ by a Duncan's multiple range test

는 미백 기능성 화장품 원료로 이용 가능성이 있을 것으로 기 대되었다.

\section{와송 추출물의 collagenase, elastase 저해효과}

세포 외 기질(extracellular matrix)의 주요 구성 성분인 collagen 은 피부의 섬유아세포에서 생성되는 주요 기질 단백질로 생체 단백질 총 중량의 약 $30 \%$ 를 차지하며 견고한 3 중 나선구조를 가지고 있다. Collagen의 주된 기능으로는 피부의 기계적 견고 성, 결합조직의 저항력과 조직의 결합력, 세포 접착의 지탱, 세 포 분할과 분화의 유도 등이 알려져 있다(Jeroma 등, 1998). 이 러한 collagen은 연령 및 자외선 조사에 의한 광노화에 의해 감 소하고, 이는 피부의 주름 형성과 밀접한 연관이 있다고 알려 져 있다(El-Domyati 등, 2002). 와송 열수 추출물과 $50 \%$ ethanol 추출물을 $50-200 \mu \mathrm{g} / \mathrm{mL}$ phenolic 농도로 조절하여 collagenase 저해활성을 측정한 결과는 Fig. $6 \mathrm{~A}$ 와 같이 와송 열 수 추출물에서는 38.89-61.69\%의 collagenase 억제효과가 확인 되었고, $50 \%$ ethanol 추출물에서는 $75.95-85.02 \%$ 의 억제효과가 확인되어, $50 \%$ ethanol 추출물이 열수 추출물에 비해 collagenase 에 대한 억제효과가 더 우수함을 확인할 수 있었다. 이러한 결 과를 통해 와송 추출물이 피부 내에서 collagenase의 활성을 억 
제함으로서 collagen의 분해를 막아 주름 개선을 위한 기능성 화장품 소재로 활용이 가능할 것으로 판단되었다. Lee 등(2004) 의 유백피 추출물의 collagenase 저해활성을 측정한 결과에서 유 백피 $100 \mathrm{ppm}$ 이 27.6\%를 나타내었으며, Barrantes와 Guinea (2003)의 알로에 추출물의 collagenase 저해활성을 확인한 결과 에서는 $37.1 \%$ 를 나타내었다는 연구 결과와 비교하면, 와송 $50 \%$ ethanol 추출물의 collagenase 억제효과가 매우 우수한 것으로 확인되었다.

Elastase는 진피 내 피부탄력을 유지하는데 중요한 기질 단백 질인 elastin을 분해하는 효소로, 다른 중요한 기질 단백질인 collagen을 분해할 수 있는 비특이적 가수분해 효소이다. Elastase 저해제는 주로 피부 주름을 개선하는 작용을 나타내며 ursolic acid, vitamin C 등이 대표적인 elstase 저해제로 이용되 고 있다(Roth 등, 1980). 또한 elstase는 체내의 elastin을 분해 하는 백혈구 과립 효소 중의 하나로, 이상조직에서는 그 효소 의 활성이 극히 높아 조직 파괴에 직접적인 원인이 되며 피부 주름과 탄력성 손실을 유발한다(Dewitt 등, 1981). 이러한 주름 생성과 관련된 elastase 저해활성을 측정한 결과는 Fig. $6 \mathrm{~B}$ 와 같 이 열수 추출물보다 $50 \%$ ethanol 추출물에서 elastase 억제효과 가 훨씬 더 우수하였으며, $50 \%$ ethanol 추출물 $200 \mu \mathrm{g} / \mathrm{mL}$ phenolic 농도에서 $63.65 \%$ 의 elastase 저해 효과가 확인되었다. 또한 대조구로 사용한 epigallocatechin-gallate $50-200 \mu \mathrm{g} / \mathrm{mL}$ 에 서 22.11-51.16\%의 억제효과와 비교하면 와송 $50 \%$ ethanol 추 출물의 elastase 억제효능이 더 뛰어남을 알 수 있었다. 이상의 결과를 통해 와송 $50 \%$ ethanol 추출물은 우수한 collagenase와 elastase 저해효능을 가지고 있어 향후 주름 개선용 화장품 원 료로 활용이 가능할 것이라 판단되었다.

\section{초 록}

와송에 함유된 phenol성 물질은 $50 \%$ ethanol을 용매로 하여 추 출하였을 때 $10.56 \pm 0.32 \mathrm{mg} / \mathrm{g}$ 의 함량을 나타내었다. 와송 추출 물의 항산화력을 측정한 결과 전자공여능은 $200 \mu \mathrm{g} / \mathrm{mL}$ phenolic 농도에서 열수 추출물과 $50 \%$ ethanol 추출물 모두 $80.0 \%$ 이상 으로 높은 효과가 확인되었다. ABTS radical cation decolorization 을 측정한 결과에서 와송 열수와 $50 \%$ ethanol 추출물 모두 $95.0 \%$ 이상의 높은 항산화 활성이 측정되었다. Antioxidant protection factor $(\mathrm{PF})$ 는 열수 추출물이 $50 \%$ ethanol 추출물에 비해 높은 PF값을 나타내었으며, thiobarbituric acid reactive substance (TBARs) 저해효과는 $50 \%$ ethanol 추출물이 열수 추 출물 보다 높은 항산화력을 나타내었다. 와송 추출물의 항고혈 압 효과를 살펴보기 위하여 angiotensin converting enzyme 저 해활성을 측정한 결과 $200 \mu \mathrm{g} / \mathrm{mL}$ phenolic의 처리농도에서 열 수와 $50 \%$ ethanol 추출물이 각각 $6.67 \%$ 과 $7.98 \%$ 로 낮게 나타 났다. 와송 추출물의 XOase 저해활성은 $50 \%$ ethanol 추출물 $200 \mu \mathrm{g} / \mathrm{mL}$ phenolic 농도에서 $60.85 \%$ 의 저해율을 나타내었으 며, tyrosinase 억제활성은 $50 \%$ ethanol 추출물 $200 \mu \mathrm{g} / \mathrm{mL}$ phenolic 농도에서 $64.59 \%$ 로 나타나 대조구인 kojic acid 보다 미백 효과가 더 우수함을 입증하였다. 주름 생성과 관련된 collagenase 억제효과는 $50 \%$ ethanol 추출물의 $50200 \mu \mathrm{g} / \mathrm{mL}$ phenolic 농도에서 $75.9585 .02 \%$ 로 매우 우수하였으며, 대조구인 epigallocatechin-gallate의 $68.9176 .64 \%$ 보다 다소 높았다. Elastase 저해활성도 $50 \%$ ethanol 추출물 $200 \mu \mathrm{g} / \mathrm{mL}$ phenolic 농도에서 최대 $63.65 \%$ 의 저해효과를 나타내어 와송 $50 \%$ ethanol 추출물 의 주름개선 효과가 매우 우수함을 확인하였다. 이상의 결과를 통해 와송 추출물의 항산화 활성, 통풍 억제효능, 미백 및 주름 개선 등의 기능성 검증을 위한 기초 연구 자료로 활용이 가능 할 것으로 예상되며, 향후 추가적인 연구를 통해 와송 추출물 을 기능성 식품 및 화장품, 의약품 소재로 적용이 가능할 것으 로 판단되었다.

Keywords 건강기능식품 · 미용식품 · 생리활성 · 와송 · 항산 화 활성

\section{References}

Andarwulan N, Shetty K (1999) Phenolic content in differentiated tissue cultures of untansformed and Ahrobacterium-transformed roots of anise (Pimpinella anisum L.). J Agric Food Chem 47: 1776-1780

Aoshima H, Tsumoue H, Koda H, Kiso Y (2004) Aging of whiskey increases 1,1-diphenyl-2-picrylhydrazyl radical scavenging activity. J Agric Food Chem 52: 5240-5244

Aruoma OI (1998) Free radical, oxidatove stress and antioxidants in human health and disease. J Am Oil Chem Soc 75: 199-212

Azuma K, Nakayama M, Koshika M, Ippoushi K, Yamaguchi Y, Kohata K, Yamauchi Y, Ito H, Higashio H (1999) Phenolic antioxidants from the leaves of Corchorus olitorius L. J Agric Food Chem 47: 3963-3966

Barrantes E, Guinea M (2003) Inhibition of collagenase and metalloproteinases by aloins and aloe gel. Life Sci 72: 843-850

Blois MS (1958) Antioxidant determination by the use of a stable free radical. Nature 26: 1199-1200

Buege JA, Aust SD (1978) Microsomal lipid peroxidation. Method in enzymol 105: 302-310

Choe SY, Yang KH (1982) Toxicological studies of antioxidants buthylated hydroxytoluene (BHT) and buthylated hydroxy anisole (BHA). Korean J Soc Food Sci Technol 14: 283-288

Choi HS, Kim MG, Shin JJ, Pack JM, Lee JS (2003) The antioxidant activities of the some commercial teas. J Korean Soc Food Sci Nutr 32: 723-727

Choi SY, Kim JG, Sung NJ (2008) Studies on the physicochemical characteristics and NDMA formation of Orostachys japonicus A. Berger. J Korean Soc Food Sci Nutr 21: 148-156

Cushman DW, Cheung HS (1971) Spectrophotometic assay and properties of the angiotensin-converting enzyme of rabbit lung. Biochem Pharmacol 20: $1637-1648$

Dewitt DL, Rollins TE, Day JS, Gauger JA, Smith WL (1981) Orientation of the active site, and antigenic determinants of prostaglandin endoperoxide of synthase in the Endoplasmic reticulum. J Biol Chem 256: 1037510382

El-Domyati M, Attia S, Saleh F, Brown D, Birk DE, Gasparro F, Ahmad H, Uitto J (2002) Intrinsic aging vs. photoaging: a comparative histopathological, immuno-histo chemical, and ultra-structural study of skin. Exp Dermatol 11: 398-405

Folin O, Denis W (1912) On phosphotungastic-phosphomolybdic compounds as color reagents. J Biol Chem 12: 239-249

Hearing VJ Jr (1987) Mammalian monophenol monooxygenase(Tyrosinase): purification, properties, and reactions catalyzed. Methods Enzymol 142: $154-165$

Huang MT, Ho CT, Lee CY (1992) Phenolic compounds in food. In Penolic compounds in food and their efects on health II. American Chemical Society, New York 
Imokawa G, Mishima Y (1980) Isolation and characterization of tyrosinase inhibitors and their differential action on melanogenic subcelluar compartments in amelanotic and melanomas. Br J Dermatol 103: 625633

Jeroma SP, Gabrielle L, Raul F (1998) Identification of collagen fibril in scleroderma skin. J Invest Dermatol 90: 48-54

Ju JC, Shin JH, Lee SJ, Cho HS, Sung NJ (2006) Antioxidative activity of hot water extracts from medicinal plants. J Korean Soc Food Sci Nutr 35: 714

Jung SW, Kim MK (2003) Effect of dried powders of chamomile, sage, and green tea on antioxidative capacity in 15-month-old rats. Korean Nutr Soc 36: 699-710

Kim EY, Baik IH, Kim JH, Kim SR, Rhyu MR (2004a) Screening of the antioxidant activity of some medicinal plants. Korean J Food Sci Technol 36: 333-338

Kim JH (2006) Biological activities of phenolic compound from Herb and oriental medicinal resource. Dissertation, Sangju National University

Kim JK (1984) Illustrated natural drugs encyclopedia. Namsandang, Seoul

Kim JP, Chin IJ, Cho HK, Ham IH, Whang WK (2004b) The antioxidant and the antidiabetic effects of ethanol extract from biofuntional foods prescriptions. Korean J Pharmacogn 35: 98-103

Kim JY, Jung EJ, Won YS, Lee JH, Shin DY, Seo KI (2012) Cultivated Orostachys japonicus induces apoptosis in human colon cancer cells. KOREAN J FOOD SCI TECHNOL 44: 317-323

Kim JY, Maeng YS, Lee KY (1995) Antioxidative effects of soybean extracts by using various solvents. Korean J Food Sci Technol 27: 635-639

Kim MR, Hwang JH, Yun JK, Han KH, Do EJ, Lee JS, Lee EJ, Kim JB (2011) Antioxidation and antiaging effect of mixed extract from Korean medicinal herbs. Korean J Herbology 26: 111-117

Koh JH, Hwang MO, Moon JS, Hwang SY, Son JY (2005) Antioxidative and antimicrobial activities of pomegranate seed extracts. Korean J Food Cookery Sci 21: 171-179

Kraunsoe JAE, Claridge TDW, Lowe G (1996) Inhibition of human leukocyte and porcine pancreatic elastase by homologues of bovine pancreatic tyrosin inhibitor. Biochem 35: 9090-9096

Kwon J, Han KS (2004) Effects of Orostachys japonicus A. Berger on the immune system. Korean J Med Crop Sci 12: 315-320

Kyrtopoulos SA (1989) N-nitroso compound formation in human gastric juice. Cancer Surveys 8: 423-442

Larson RA (1988) The antioxidant of higher plants. Phytochem 27: 969-978

Laskin JD, Piccinini LA (1986) Tyrosinase isozyme heterogeneity in differentiating B-16/C3 melanoma. J Biol Chem 261: 16626-16635
Lee SJ, Song EJ, Lee SY, Kim KBWR, Kim SJ, Yoon SY, lee CJ, Ahn DH (2009) Antioxidant activity of leaf, stem and root extracts from Orostachys japonicus and their heat and $\mathrm{pH}$ stabilities. J Korean Soc Food Sci Nutr 38(11): 1571-1579

Lee TW, Kim SN, Jee UK, Hwang SJ (2004) Anti-wrinkle effect of pressure sensitive adhesive hydrogel patches containing Ulmi cortex extract. J Kor Pharm Sci 34: 193-199

Miyoshi D, Richard LS (1975) Pulmonary angiotensin converting enzyme. J Biol Chem 250: 6762-6768

Nam SH, Kang MY (2000) Screening of antioxidative activity of hot-water extracts from medicinal plants. J Korean Soc Agric Chem Biotechnol 43 : $141-147$

Noro T, Fukushima S (1988) Inhibitors of xanthine oxidase from the flowers and buds of Daphne genkwa. Chem Pharm Bull 31: 3984-3988

Park HJ, Lim SC, Lee MS, Young HS (1994) Triterpene and steroids from Orostachys japonicus. Korean J Pharmacogn 25: 20-23

Park HJ, Young HS, Kim JO, Rhee SH, Choi JS (1991) A study on the chemical constituents of Orostachys japonicus A. Berger. Korean J Pharmacogn 22: 78-84

Park JG, Park JC, Hur JM, Park SJ, Choi DR, Shin DY, Park KY, Cho HW, Kim MS (2000) Phenolic compounds from Orostachys japonicus having anti-HIV-1 protease activity. Nat Prod Sci 6: 117-121

Park SJ, Lee HY, Oh DH (2003) Free radical scavenging effect of seed and skin extracts from campell early grape (Viris labruscana B.). J Korean Soc Food Sci Nutr 32: 115-118

Pellegrin N, Roberta R, Min Y, Catherine RE (1998) Screening of diatry carotenoids and carotenoid-rich fruit extracts for antioxidant activities applying 2,2'-Azinobis (3-ethylenebenzothiazoline-6-sulfonic acid) radical cation decolorization assay. Method in Enzymol 299: 379-389

Roth GJ, Siok CJ, Ozols J (1980) Structural characteristics of prostaglandin synthetase from sheep vesicular gland. J Biol Chem 255: 1301-1304

Shin HL (2003) Biological acivity of phenol compound from muberry fruits. Dissertation, Sangju National University

Stirpe F, Corte ED (1969) The regulation of rat liver xanthine oxidase conversicon in vitro of the enzyme activity from dehydrogenase (type D) to oxidase (type O). J Biol Chem 244: 3855-3861

Won YS, Lee JH, Kwon, SJ, Ahn DU, Shin DY, Seo KI (2014) Anticancer effects of cultivated Orostachys japonicus on human prostate cancer cells. J Korean Soc Food Sci Nutr 43: 67-73

Wûnsch E, Heindrich HG (1963) Zur quantitativen bestimmung der collagenase. Hoppe-Seyler's. Physiol Chem 333: 149-151 